\title{
Pengaruh STAD Berbantuan Buku Saku Terhadap Hasil Belajar Siswa Kelas X MAN 1 Pontianak
}

\author{
Sellina Yessi Wulandari, Laili Fitri Yeni, Titin
}

(C) 2020 JEMS (Jurnal Edukasi Matematika dan Sains)

This is an open access article under the CC-BY-SA license (https://creativecommons.org/licenses/bysa/4.0/) ISSN 2337-9049 (print), ISSN 2502-4671 (online)

\begin{abstract}
Abstrak:
Penelitian ini bertujuan untuk mengetahui pengaruh model pembelajaran Student Team Achivement Division berbantuan buku saku terhadap hasil belajar siswa MAN 1 Pontianak di kelas $X$ pada materi keanekaragaman hayati. Bentuk penelitian yang digunakan adalah Quasy Experimental Design dengan rancangan penelitian Nonequivalent Control Group Design. Sampel penelitian terdiri dari 2 kelas yaitu kelas $X$ MIA 3 sebagai kelas eksperimen dan X MIA 4 sebagai kelas kontrol. Instrumen penelitian berupa tes pilihan ganda sebanyak 20 butir soal. Hasil penelitian menunjukan skor ratarata hasil belajar kelas eksperimen sebanyak 17,57 sedangkan pada kelas kontrol 16,29. Berdasarkan analisis data dengan menggunakan uji $\mathrm{U}$ Mann-Whitney $\mathrm{Z}_{\text {hitung }}<$ $\mathrm{Z}_{\text {tabel }}$ menunjukkan terdapat perbedaan hasil belajar siswa yang diajar dengan menggunakan model kooperatif Student Team Achivement Division dengan model konvensional. Nilai Effect size diperoleh sebesar 0,69 dengan kategori sedang, memberikan pengaruh sebesar $25,49 \%$. Disimpulkan bahwa model pembelajaran STAD berpengaruh terhadap hasil belajar siswa pada materi keanekaragaman hayati.
\end{abstract}

Kata Kunci: Hasil Belajar; STAD; Keanekaragaman Hayati

\begin{abstract}
:
The research was purposed to know of cooperative learning model Student Team Achivement Division aided pocket book for learning outcomes on biodiversity material in class X MAN 1 Pontianak. The shape of the research is used Quasy Experimental Design with Nonequivalent Control Group Design. The sample research consisted of two classes, namely class as a class experiment X MIA 3 and X MIA 4 as the control class. The research instrument used was a multiple choice test included 20 questions. The results of the research showed the average post-test score 17,57 experimental classband control class is 16,29 . Based on data analysis using the U Mann-Whitney test was obtained $\mathrm{z}_{\text {test }} \geq \mathrm{z}_{\text {tab }}$ showed that there is difference between learning outcome of student taught using cooperative learning Student Team Achivement Division aided pocket book to those using conventional models. Based on the calculation of Effect Size cooperative learning Student Team Achivement Division aided pocket book on biodiversity material give contributed $24,51 \%$ of the student learning outcomes. Thus concluded that cooperative cooperative learning Student Team Achivement Division aided pocket book on student learning outcomes in biodiversity material.
\end{abstract}

Keywords: Learning Outcome; STAD; Biodiversity

\section{Pendahuluan}

Pendidikan merupakan pendewasaan peserta didik agar daat mengembangkan bakat, potensi dan keterampilan yang dimiliki dalam menjalani kehidupan oleh karena itu sudah seharusnya pendidikan didesain guna memberikan pemahaman serta meningkatkan prestasi

\footnotetext{
Sellina Yessi Wulandari, FKIP Universitas Tanjungpura Pontianak Sellinayessi97@gmail.com

Laili Fitri Yeni, FKIP Universitas Tanjungpura Pontianak lailifitri74@gmail.com
}

Titin, FKIP Universitas Tanjungpura Pontianak titin@fkip.untan.ac.id 
belajar peserta didik (Daryanto, 2016). Pendidikan di Indonesia umumnya masih sangat rendah dibandingkan dengan negara-negara terdekatnya seperti Singapura dan Malaysia. Rendahnya mutu pendidikan di Indonesia menuntut perlunya perbaikan sistem pendidikan nasional. Hal inilah yang menjadi salah satu alasan pemerintah menghendaki adanya perubahan kurikulum.

Kurikulum 2013 lebih mengedepankan peran siswa dalam proses pembelajaran (Depdiknas: 2003, Rahmawati: 2014). Kurikulum 2013 menuntut guru supaya melaksanakan pembelajaran saintifik dimana guru bisa sebagai sumber belajar, fasilitator, demonstrator, pembimbing dan motivator dalam pembelajaran (Haryani, 2013). Pembelajaran yang baik yaitu pembelajaran dimana guru telah membuat sebuah rencana pelaksanaan pembelajaran (RPP) yang sesuai dengan kurikulum yang berlaku saat pembelajaran berlangsung. Menurut Nazarudin (2007) perangkat pembelajaran adalah suatu persiapan yang disusun guru dengan baik agar dalam pelaksanaan dan evaluasi pembelajaran dapat dilakukan secara sistematis dan memperoleh hasil yang diinginkan.

Hasil belajar merupakan hasil nyata yang diperoleh peserta didik setelah melakukan suatu proses belajar. Menurut Nurtanto dan Sofyan (2015) hasil belajar meliputi tiga ranah kemampuan, yaitu kognitif, afektif dan psikomotorik. Kemampuan dalam ranah kognitif diperoleh dari hasil tes yang diberikan kepada peserta didik, sedangkan psikomotorik atau keterampilan diperoleh dari seberapa minatnya peserta didik dengan materi yang diajarkan seperti sikap kritis dan sikap ilmiah yang ditunjukan oleh peserta didik saat pelajaran berlangsung. Perolehan hasil belajar setiap peserta didik berbeda-beda dikarenakan ada faktor yang mempegaruhinya. Terdapat dua faktor yang dapat mempengaruhi hasil belajar yaitu faktor internal atau faktor yang berasal dari diri sendiri seperti perilaku, bakan, jasamani dan rohani. Faktor kedua yang mempengaruhi hasil belajar adalah faktor eksternal yang mana faktor ini berasal dari luar diri sendiri meliputi keluarga, sekolah, guru dan masyarakat (Slameto, 2010).

Berdasarkan hasil wawancara dengan guru Biologi Madrasah Aliyah Negeri 1 Pontianak pada tanggal 8 Januari 2019 diketahui bahwa materi keanekaragaman hayati merupakan materi yang nilainya lebih rendah dibandingkan dengan materi yang lainnya, rendahnya hasil belajar siswa pada materi keanekaragaman hayati dapat dilihat dari nilai rata-rata ulangan harian siswa kelas X Madrasah Aliyah Negeri 1 Pontianak tahun pelajaran 2018/2019.

Nilai rata-rata ulangan harian siswa menunjukkan pada ketiga kelas yaitu MIA 1, MIA 2 dan MIA 3 belum mencapai ketuntasan pada materi keanekaragaman hayati yang ditetapkan oleh sekolah dengan nilai 75. Berdasarkan silabus materi keanekaragaman hayati termasuk salah satu materi di kelas X semester Ganjil. Adapun sub materi pada keanekaragaman hayati ada 5 yaitu konsep keanekaragaman gen, jenis, ekosistem, keanekaragaman hayati Indonesia flora dan fauna, penyebarannya berdasarkan garis Wallace dan garis Webber, keunikan hutan hujan tropis Indonesia dan Pemanfaatan keanekaragaman hayati Indonesia serta upaya pelestarian keanekaragaman hayati Indonesia Kompetensi dasarnya meliputi 3.2 menganalisis berbagai tingkat keanekaragaman hayati di Indonesia beserta ancaman dan pelestariannya. Tujuan pembelajaran pada materi ini yaitu peserta didik dapat menjelaskan berbagai macam tingkatan keanekaragaman hayati gen, jenis dan ekosistem, membedakan berbagai tingkatan keanekaragaman gen, jenis dan ekosistem, mengidentifikasi wilayah penyebaran keanekaragaman hayati di Indonesia berdasarkan garis Wallace dan garis Webber serta mengelompokkan berbagai flora dan fauna di Indonesia berdasarkan garis wallace dan garis weber 
Materi keanekaragaman hayati nilainya masih rendah dibandingkan dengan materi yang lainnya. Rendahnya materi keanekaragaman hayati terdapat pada konsep keanekaragaman gen, dan jenis serta persebaran flora dan fauna. Hal ini disebabkan karena siswa masih keliru dalam membedakan pengertian antara keanekaragaman gen dan jenis serta mengelompokkan contoh-contoh hewan dan tumbuhan yang termasuk kedalam keanekaragaman gen dan jenis. Selain itu, pada konsep persebaran flora dan fauna siswa masih kesulitan dalam memberikan contoh hewan serta tumbuhan yang berada di kawasan Indonesia bagian Timur, Barat dan peralihan.

Berdasarkan hasil wawancara guru masih menerapkan model pembelajaran konvensional dengan metode ceramah dan tanya jawab. Menurut Djamarah \& Zein (2013) model konvensional merupakan model pembelajaran tradisional sehingga siswa hanya mengandalkan informasi dari gurunya. Adapun metode yang digunakan yaitu metode ceramah, diskusi dan tanya jawab. Metode ceramah merupakan metode yang bersifat satu arah yang membuat siswa mudah lupa dan bersifat verbalisme (Daryanto, 2013). Guru pernah melakukan diskusi kelompok dalam pembelajaran, namun pembagian kelompok dilakukan hanya berdasarkan tempat duduk siswa. Sehingga pembagian kelompok tidak menurut kemampuan akademik dan terdapat beberapa kelompok yang didominasi oleh siswa-siswa berkemampuan tinggi yang mengakibatkan tidak semua siswa terlibat aktif dalam kelompoknya.

Menyikapi masalah tersebut perlu adanya alternatif dalam memilih model pembelajaran. Pemilihan model pembelajaran harus sesuai dengan karakteristik materi yang akan disampaikan agar dapat mencapai tujuan yang diinginkan. Model pembelajaran kooperatif Student Team Achievement Division (STAD) merupakan model pembelajaran yang mengutamakan adanya interaksi diantara siswa (Zulhartati: 2012, Utomo: 2012, Khairiyah: 2011). Menurut (Rusman, 2014) pembagian kelompok siswa dibagi secara heterogen (siswa yang berkemampuan tinggi, sedang dan rendah). Pembagian kelompok juga melibatkan peran siswa dalam tutor sebaya. Pembagian kelompok menurut tutor sebaya mengajarkan siswa bekerja bersama-sama untuk mempelajari dan bertanggung jawab atas pelajaran mereka sendiri dan pembelajaran orang lain. Menurut Majoka (2010) adapun karakteristik dalam pembelajaran STAD terletak pada kegiatan belajar tim dan penghargaan kelompok. Anggota kelompok harus menguasai materi yang diajarkan oleh guru untuk mempersiapkan diri dalam menjalani kuis. Setelah peserta didik menjalani kuis, skor individu akan disumbangkan ke kelompok. Pada pembelajaran STAD peserta didik tidak hanya bertanggung jawab terhadap dirinya sendiri melainkan pada kelompoknya. Setelah itu, siswa akan diberikan penghargaan sesuai dengan kemampuan kelompoknya. Menurut Rusman (2014) penghargaan pada model STAD berupa sertifikat. Adapun sertifikat tersebut berisi penghargaan super team, good team dan great team.

Kurang terlibatnya peserta didik dalam proses pembelajaran menjadi salah satu penyebab alasan hasil belajar siswa rendah. Ketersediaan LCD di sekolah MAN 1 Pontianak masih terbatas, guru pernah menggunakan media power point tetapi media power point yang ditampilkan oleh guru menampilkan teks lebih banyak dibandingkan dengan gambar. Untuk membedakan keanekaragaman gen siswa masih kesulitan karena buku yang digunakan disekolah merupakan buku LKPD. Buku LKPD yang diberikan berwarna hitam putih dengan menampilkan teks lebih banyak dibandingkan dengan gambar, sehingga siswa masih kesulitan dalam membedakan contoh dari berbagai macam tingkatan keanekaragaman hayati. Menyikapi masalah tersebut perlu adanya alternatif dalam memilih model pembelajaran. Buku saku 
merupakan buku yang berukuran kecil yang dapat di simpan di saku. Ukurannya yang relative kecil memuat berbagai gambar-gambar yang berwarna tertentu merupakan keunggulan dari buku saku. Buku saku dalam penelitian ini berisikan banyak gambar dan sedikit uraian. Siswa cenderung meyukai bacaan yang menarik dengan sedikit uraian dan banyak gambar atau warna Warna juga dapat menjadi bentuk komunikasi non-verbal yang dapat menyampaikan pesan secara instan dan lebih bermakna (Laksita, 2014). Menurut Ardian (2016) buku saku tidak hanya digunakan oleh siswa, tetapi guru juga terbantu dengan adanya media buku saku. Penggunaan media pembelajaran dapat mewakili apa yang kurang mampu guru ucapkan melalui kata atau kalimat tertentu. Dengan demikian siswa akan kesulitan dalam mencerna materi pembelajaran. Fungsi dari media merupakan alat yang digunakan untuk membantu dalam proses pembelajaran, yakni menunjang penggunaan model pembelajaran yang digunakan guru (Djamarah \& Zain). Dari uraian diatas peneliti tertarik untuk melakukan penelitian yang berjudul "Pengaruh Model Pembelajaran STAD Berbantuan Buku Saku Terhadap Hasil Belajar Siswa Materi Keanekaragaman Hayati kelas X di MAN 1 Pontianak".

\section{Metode}

Metode yang digunakan dalam penelitian ini adalah metode eksperimen. Pada penelitian ini, tidak semua variabel dapat dikontrol oleh peneliti karena itu jenis eksperimen yang digunakan adalah eksperimen semu (Quasi Eksperimental Design) dengan rancangan non equivalent control group design. Pola non equivalent control group design sebagai berikut:

\begin{tabular}{lll}
$\mathrm{O}_{1}$ & $\mathrm{X}$ & $\mathrm{O}_{2}$ \\
\hline $\mathrm{O}_{3}$ & $\mathrm{O}_{4}$
\end{tabular}

Keterangan :

O1= Pre-test pada kelas eksperimen

O2 $=$ Post-test pada kelas eksperimen

$\mathrm{O} 3=$ Pre-test pada kelas kontrol

$\mathrm{O} 4=$ Post-test pada kelas kontrol

$X=$ Perlakuan dengan model pembelajaran kooperatif STAD (Sugiyono, 2016)

Populasi dalam penelitian ini adalah seluruh peserta didik kelas X MIA 1, X MIA 2, X MIA 3 dan X MIA 4 di MAN 1 Pontianak tahun ajaran 2018/2019. Sampel dalam penelitian ini diambil dengan memberikan soal pre-test kepada populasi. Kelas yang dijadikan sampel yaitu kelas yang mempunyai kemampuan rata-rata hampir sama dan standar deviasi yang relatif sama dari skor pre-test. Sampel dalam penelitian ini terdiri dari dua kelas yaitu kelas $\mathrm{X}$ MIA 3 sebagai kelas eskperimen dan kelas X MIA 4 sebagai kelas kontrol.

Variabel pada penelitian ini terdiri dari 2 variabel bebas dan variabel terikat. Variabel bebas yakni penggunaan model kooperatif STAD berbantuan buku saku sedangkan variabel terikatnya yakni hasil belajar siswa pada materi keanekeragaman hayati. Variabel kontrol yakni guru yang mengajar, materi yang diajar dan waktu. Instrumen yang digunakan pada penelitian ini yaitu tes pilihan ganda yang berjumlah 20 soal, RPP (Rencana Pelaksanaan Pembelajaran), LKPD (Lembar Kerja Peserta Didik) dan media buku saku.

Teknik pengumpulan data yang digunakan dalam penelitian ini adalah tes pre-test dan post-test. Teknik analisis data yang digunakan berupa uji normalitas. Uji homogenitas, uji $\mathrm{t}$, uji U Mann Whitney, perhitungan effect size. Uji normalitas digunakan untuk mengetahui sampel 
dari populasi berdistribusi normal atau tidak. Uji homogenitas varians menggunakan uji $\mathrm{F}$ digunakan untuk mengetahui apakah kedua varians sama atau tidak. Uji t digunakan apabila kedua data normal dan homegen. Uji U-Mann Whitney digunakan untuk mengetahui apakah terdapat perbedaan antara kelas kontrol dengan kelas eksperimen sedangkan uji effect size untuk mengetahui pengaruh model pembelajaran STAD berbantuan buku saku terhaap hasilbelajar siswa pada materi keanekaragaman hayati kelas X MAN 1 Pontianak.

\section{Hasil dan Pembahasan}

Penelitian ini dilakukan pada kelas X MIA 3 sebagai kelas eksperimen dan kelas X MIA 4 sebagai kelas kontrol di MAN 1 Pontianak dengan teknik pengambilan sampel intact group. Setelah dilakukan analisis data, diperoleh rata- rata hasil belajar siswa sebagai berikut:

\begin{tabular}{ccccc}
\multicolumn{2}{c}{ Tabel 1. Rata-rata Post-test dan Standar Deviasi Siswa pada Materi Keanekaragaman Hayati } \\
\hline \multirow{2}{*}{ Skor } & \multicolumn{2}{c}{ Kelas Eksperimen } & \multicolumn{3}{c}{ Kelas Kontrol } \\
\cline { 2 - 5 } Post-test & $\overline{\mathrm{x}}$ & $\mathrm{SD}$ & $\overline{\mathrm{x}}$ & SD \\
& 17,57 & 1,55 & 16,29 & 1,86 \\
\hline
\end{tabular}

Berdasarkan Tabel 1. diketahui bahwa rata-rata hasil belajar siswa di kelas eksperimen lebih tinggi dibandingkan dengan kelas kontrol, hal ini dikarenakan adanya perbedaan perlakuan dimana kelas eksperimen diajar dengan model pembelajaran kooperatif tipe STAD berbantuan buku saku sedangkan pada kelas kontrol diajar dengan model pembelajaran konvensional berbantuan media power point. Untuk mengetahui apakah terdapat perbedaan hasil belajar antara siswa kelas eksperimen dan kelas kontrol, serta untuk mengetahui seberapa besar pengaruh yang diberikan, maka data hasil post-test yang berupa skor dianalisis terlebih dahulu dengan uji prasyarat, yaitu uji normalitas. Jumlah data yang diperoleh $>30$, maka uji normalitas yang digunakan adalah uji Chi kuadrat. Hasil uji normalitas dapat dilihat pada Tabel 2.

Tabel 2. Hasil Uji Normalitas Data Post-test Kelas Eksperimen dan Kontrol

\begin{tabular}{llllll}
\hline Kelas & $\chi^{2}{ }_{\text {hitung }}$ & $\chi^{2}{ }_{\text {tabel }}$ & Kriteria Normal & Keterangan \\
\hline Eksperimen & 17,34 & 7,815 & $\chi_{\text {hitung }}^{2} \chi^{2}{ }_{\text {tabel }}$ & Maka Data Tidak \\
\cline { 1 - 4 } Kontrol & 26,28 & 7,815 & $\chi_{\text {hitung }}^{2} \chi^{2}{ }_{\text {tabel }}$ & & Berdistribusi Normal \\
\hline
\end{tabular}

Dilihat dari tabel 2. diperoleh data hasil post-test peserta didik tidak berdistribusi normal, selanjutnya dilakukan uji U Mann- Whitney. Hasil uji U Mann-Whitney dapat dilihat pada Tabel 3.

Tabel 3. Hasil Uji U Mann- Whitney Data Post-test Kelas Eksperimen dan Kontrol

\begin{tabular}{cccclc}
\hline Data & $\mathbf{Z}_{\text {hitung }}$ & $\mathbf{Z}_{\text {tabel }}$ & $\begin{array}{c}\text { Kriteria } \\
\text { Homogen }\end{array}$ & \multicolumn{2}{c}{ Keterangan } \\
\hline Post-test & $-2,15$ & $-1,96$ & $\mathrm{Z}_{\text {hitung }}<\mathrm{Z}_{\text {tabel }}$ & $\begin{array}{l}\text { Terdapat } \\
\text { kelas eksperimen dan kontrol }\end{array}$ \\
\hline
\end{tabular}

Dilihat dari tabel 3. Hasil uji U Mann-Whitney data post-test pada kelas eksperimen dan kontrol yaitu $\mathrm{Z}_{\text {hitung }}<\mathrm{Z}_{\text {tabel }}$ yang berarti terdapat perbedaan hasil belajar siswa antara kelas eksperimen dengan kelas kontrol Untuk mengetahui seberapa besar pengaruh perlakuan pada kelas eksperimen, dilakukan perhitungan Effect Size (Sutrisno, 2010). Hasil perhitungan 
menunjukkan nilai dengan kategori tinggi, yaitu 0,69. Jika nilai tersebut dikonversikan ke dalam tabel kurva normal dari tabel $\mathrm{O}-\mathrm{Z}$, maka diperoleh luas daerah sebesar 25,49. Hal ini menunjukkan bahwa perlakuan dengan menggunakan model pembelajaran kooperatif tipe STAD berbantuan buku saku memberikan kontribusi sebesar 25,49\% terhadap hasil belajar siswa MAN 1 Pontianak pada materi keanekaragaman hayati.

Penelitian ini dilaksanakan mulai tanggal 13 Agustus 2019 sampai dengan tanggal 21 Agustus 2019 di MAN 1 Pontianak pada kelas X MIA 3 sebagai kelas eksperimen yang berjumlah 37 orang dan kelas X MIA 4 sebagai kelas kontrol yang berjumlah 38 orang. Pada kelas eksperimen diajar dengan menggunakan model pembelajaran kooperatif tipe STAD berbantuan buku saku, sedangkan kelas kontrol diajar dengan model konvensional berbantuan media power point. Kegiatan pembelajaran pada masing-masing kelas terdiri atas 2 kali pertemuan dengan alokasi waktu tiap pertemuan adalah $2 \times 45$ menit.

Pada kelas eksperimen, kegiatan pembelajaran terdiri atas 5 tahap, yaitu: 1) Menyampaikan tujuan dan memotivasi siswa, 2) Pembagian kelompok, 3) penyampaian materi, 4) Kegiatan belajar dlam tim, dan 5)kuis (evaluasi); 6) penghargaan tim (Yani: 2018, Tiantong: 2013). Penggunaan buku saku sebagai media pembelajaran dimuali pada tahap kedua, yaitu pembagian kelompok. Pada tahap ini siswa dibagi menjadi 8 kelompok berdasarkan kemampuan kognitif yang berbeda (dalam satu kelompok terdapat siswa yang memiliki nilai tinggi, rendah dan sedang), setiap anggota kelompok diberikan buku saku untuk memahami materi yang akan diajarkan. Penggunaan buku saku juga dilakukan pada pada tahap kedua dan ketiga, dimana pada saat guru menjelaskan siswa sudah duduk bersama kelompok dan diberikan buku saku. Pada tahap ini, siswa tidak hanya berdiskusi, tetapi juga belajar bersama teman-teman satu kelompok dan tiap anggota kelompok bertanggungjawab untuk menjelaskan materi yang belum dipahami oleh anggota kelompoknya. Dengan kerjasama kelompok yang baik, setiap anggota kelompok akan bisa menjawab kuis individual dengan baik pula sehingga usaha mereka dalam berdiskusi nantinya akan menentukan apakah kelompok mereka mendapat penghargaan sebagai super team, great team atau good team. Menurut Junanto (2010) pengaruh positif pada model pembelajaran STAD yaitu hubungan antar ras, membantu menyemangati teman, hubungan antar teman, kerjasama, membentuk sikap di kelas dan sekolah.

Adapun pada kelas kontrol, kegiatan pembelajaran terdiri atas 3 tahap, yaitu: 1) Pendahuluan, 2) Kegiatan inti, dan 3) Penutup. Penggunaan media power point sebagai media pembelajaran digunakan pada saat guru menjelaskan materi, yaitu pada tahap kegiatan inti.Diskusi kelompok juga dilakukan pada tahap kegiatan inti, siswa dibagi menjadi 8 kelompok untuk mendiskusikan Lembar Kerja Peserta Didik (LKPD) yang telah disiapkan.Disini tampak perbedaan antara kelompok eksperimen dengan kelompok kontrol dalam kegiatan diskusi. Pada kelompok eksperimen, kegiatan diskusi tidak hanya sekedar mengisi Lembar Kerja Peserta Didik (LKPD). namun juga ditekankan bahwa siswa harus saling membantu anggota kelompoknya yang belum paham mengenai materi yang dipelajari (karena di dalam kelompok STAD terdapat siswa yang memiliki kemampuan heterogen, jadi siswa yang pintar harus membantu siswa yang kurang pintar), siswa yang belum paham juga harus berusaha untuk belajar karena nasib kelompok ditentukan oleh berhasil tidaknya anggota kelompok dalam belajar dan bekerjasama (Tran, 2013). Beda halnya dengan kelompok kontrol yang dipilih tidak berdasarkan perbedaan kemampuan kognitif, mereka juga tidak dituntut untuk saling mengajarkan hingga anggota kelompoknya paham terhadap materi yang dipelajari. 
Dengan adanya perbedaan perlakuan seperti yang telah dijabarkan di atas, maka hasil belajar siswa juga tidak sama antara kelas eksperimen dan kelas kontrol, hal tersebut dapat dilihat pada Diagram 1.

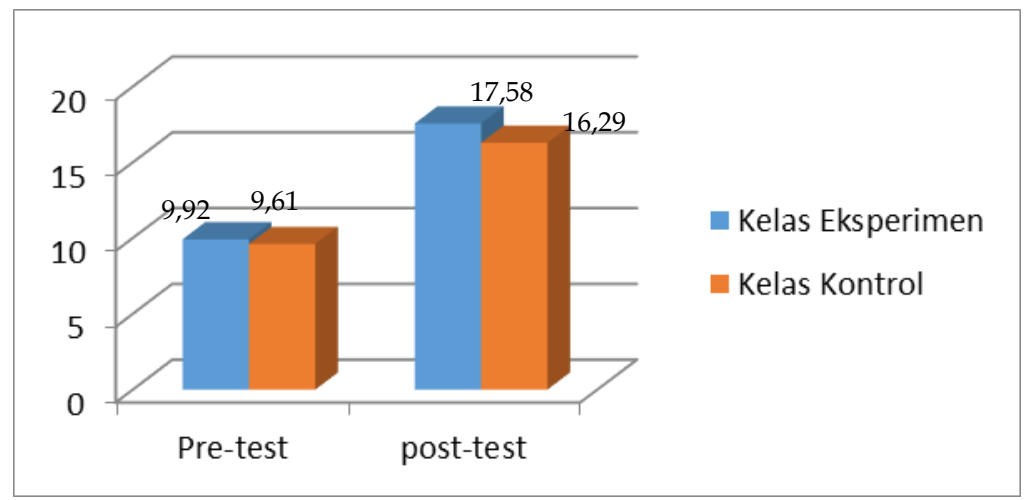

Grafik 1. Rata-rata Skor pre-test dan post-test Siswa Kelas Eksperimen dan Kelas Kontrol

Pada Grafik 1. terlihat bahwa siswa kelas eksperimen dan kontrol memiliki kemampuan yang hampir sama sebelum diberikan perlakuan, namun keduanya memiliki rata-rata hasil belajar yang berbeda setelah diberi perlakuan, dimana kelas eksperimen memiliki rata-rata hasil belajar yang lebih tinggi dibandingkan dengan siswa kelas kontrol. Penggunaan model pembelajaran kooperatif tipe STAD berbantuan buku saku pada kelas eksperimen memiliki beberapa keunggulan dibandingkan dengan pembelajaran dengan model konvensional berbantuan media power point, diantaranya adalah siswa menjadi lebih terbantu dalam belajar dan berdiskusi karena adanya buku saku sebagai media yang melengkapi buku pegangan siswa, buku saku mudah digunakan karena berisi materi yang disusun dengan bahasa yang mudah dimengerti secara padat dan jelas dibandingkan dengan buku ajar, serta dilengkapi dengan gambar yang menarik sehingga membuat siswa tertarik untuk membacanya. Menurut Anjelita (2016) Penggunaan media sebagai pendukung buku ajar dapat membantu meningkatakan hasil belajar siswa. Buku saku pada penelitian ini dapat dilihat pada Gambar 1.

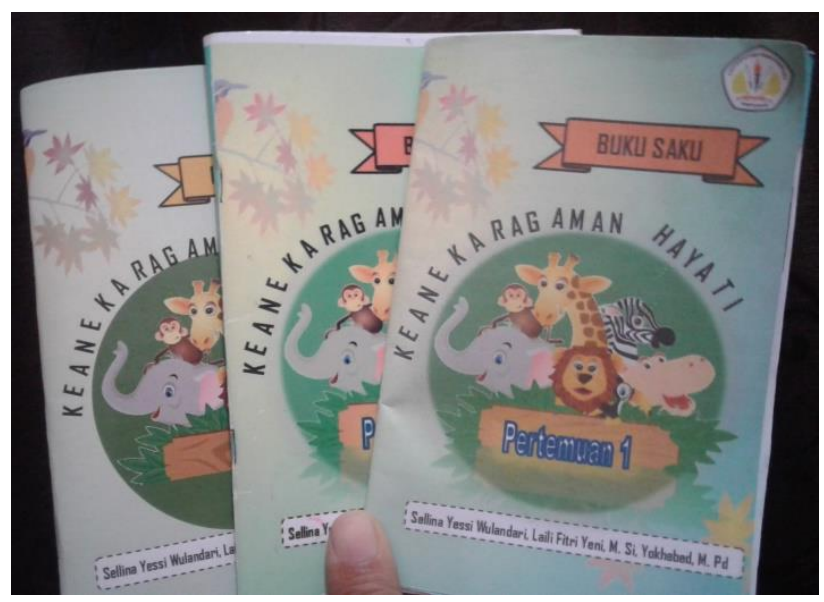

Gambar 1. Buku Saku pada Materi Keanekaragaman Hayati

Hasil belajar peserta didik pada kelas eksperimen memiliki persentase ketuntasan sebesar 91,89\% (34 orang tuntas dari 37 siswa) sedangkan kelas kontrol memiliki persentase 
ketuntasan sebesar 68,42\% (26 orang tuntas dari 38 siswa). Hal ini berarti bahwa perbedaan perlakuan menyebabkan hasil belajar yang berbeda pula.Selain itu, untuk menentukan berhasil atau tidaknya suatu pembelajaran juga dapat dilihat dari proses pembelajaran itu sendiri, hasil akhir sangat penting tetapi prosesnya juga penting. Hal ini dapat dilihat dari hasil pengerjaan Lembar Kerja Peserta Didik (LKPD) dan hasil evaluasi diakhir pembelajaran, baik kelas eksperimen maupun kelas kontrol memiliki peningkatan pada pertemuan kedua. Hal ini berarti, siswa telah mengalami proses belajar, karena siswa telah memiliki ciri-ciri perubahan dalam belajar seperti yang dikemukakan oleh Slavin (2011), perubahan tersebut salah satunya adalah adanya perubahan baru dan positif, dalam hal ini perubahan baru dan positif yang dimaksud adalah terjadinya perubahan berupa peningkatan nilai siswa pada pertemuan kedua dibandingkan pada pertemuan yang pertama. Keberhasilan belajar siswa juga dapat dilihat dari ketuntasan siswa dalam menjawab soal post- test per tujuan pembelajaran, hal ini dapat dilihat pada Tabel 5.

Tabel 4. Persentase Keberhasilan Siswa Menjawab Benar Per Tujuan Pembelajaran

\begin{tabular}{|c|c|c|c|}
\hline \multirow[t]{2}{*}{ No } & \multirow[t]{2}{*}{ Tujuan Pembelajaran } & \multicolumn{2}{|c|}{$\begin{array}{c}\text { Persentase Menjawab Benar Per Tujuan } \\
\text { Pembelajaran (\%) }\end{array}$} \\
\hline & & Eksperimen & Kontrol \\
\hline 1 & $\begin{array}{l}\text { Menjelaskan berbagai macam tingkatan } \\
\text { keanekaragaman hayati gen, jenis dan ekosistem }\end{array}$ & 91,89 & 84,21 \\
\hline 2 & $\begin{array}{l}\text { Mengelompokkan berbagai jenis makhluk hidup } \\
\text { berdasarkan konsep keanekaragaman hayati }\end{array}$ & 91,89 & 81,58 \\
\hline 3 & $\begin{array}{l}\text { Membedakan } \quad \text { berbagai } \\
\text { keanekaragaman gen, jenis dan ekosistem }\end{array}$ & 90,09 & 72,80 \\
\hline 4 & $\begin{array}{l}\text { Mengelompokan flora dan fauna di wilayah } \\
\text { persebaran Indonesia berdasarkan garis wellace } \\
\text { dan weber }\end{array}$ & 81,08 & 81,58 \\
\hline 5 & $\begin{array}{l}\text { Menganalisis berbagai flora dan fauna di } \\
\text { Indonesia berdasarkan garis wallacea dan garis } \\
\text { weber }\end{array}$ & 85,14 & 82,89 \\
\hline 6 & $\begin{array}{l}\text { Mengidentifikasi keunikan hutan hujan tropis } \\
\text { Indonesia }\end{array}$ & 89,19 & 71,05 \\
\hline 7 & $\begin{array}{l}\text { Menjelaskan pemanfaatan keanekaragaman } \\
\text { hayati }\end{array}$ & 97,30 & 89,47 \\
\hline 8 & $\begin{array}{l}\text { Menganalisis pemanfaatan keanekaragaman } \\
\text { hayati di Indonesia }\end{array}$ & 84,46 & 84,21 \\
\hline 9 & $\begin{array}{l}\text { Menganalisis upaya pelestarian keanekaragaman } \\
\text { hayati di Indonesia }\end{array}$ & 88,19 & 84,21 \\
\hline & $\begin{array}{l}\text { Rata-rata } \\
\end{array}$ & 88,91 & 81,33 \\
\hline
\end{tabular}

Berdasarkan tabel 4. diperoleh hasil bahwa kelas eksperimen memiliki persentase ratarata $88,91 \%$ sedangkan kelas kontrol 81,33\%. Hal ini menunjukkan bahwa siswa kelas eksperimen lebih menguasai konsep dibandingkan dengan siswa kelas kontrol. Secara keseluruhan, persentase ketuntasan hasil belajar siswa kelas eksperimen lebih tinggi dibandingkan dengan kelas kontrol, seperti yang tertera pada Tabel 5. Namun,kelas eksperimen memiliki ketuntasan yang lebih rendah dari kelas kontrol pada 1 butir tujuan 
pembelajaran, yaitu tujuan pembelajaran yang ke empat.

Pada tujuan pembelajaran yang keempat yaitu mengelompokkan flora dan fauna yang terdapat di wilayah persebaran Indonesia berdasarkan garis Wallacea dan garis Webber. Persentase siswa menjawab benar pada kelas kontrol lebih tinggi dibandingkan pada kelas ekperimen. Selisih persentase pada kelas eksperimen dan kontrol sebesar 0,50\%. Hal ini disebabkan karena siswa masih keliru dalam menjawab options jawaban. Kebanyakan siswa menjawab fauna daerah oriental adalah gajah, badak Sumatra dan babi rusa tetapi jawaban yang benar adalah gajah, banteng dan badak Sumatra. Hal ini disebabkan karena ciri dari hewan pada wilayah oriental yaitu mamalia yang berukuran besar sehingga siswa mengira bahwa babi rusa adalah salah satu hewan yang terdapat di wilayah oriental.

Hasil analisis skor post-test dengan menggunakan uji U Mann- Whitney menunjukkan bahwa kelompok siswa kelas eksperimen lebih baik dari kelompok siswa kelas kontrol, karena $Z_{\text {hitung }} \leq Z_{\text {tabel }}$ atau $-2,15 \leq-1,96$ atau dengan kata lain terdapat perbedaan hasil belajar antara siswa kelas eksperimen dan siswa kelas kontrol. Berdasarkan hal tersebut, dapat disimpulkan bahwa terdapat perbedaan kemampuan siswa yang diajar dengan model pembelajaran kooperatif tipe STAD berbantuan buku saku dengan siswa yang diajar dengan model pembelajaran konvensional berbantuan power point pada materi keanekaragaman hayati kelas X MAN 1 Pontianak.

Berdasarkan perhitungan diperoleh harga Effect Size sebesar 0,69 dengan kategori sedang. Nilai Effect Size jika dikonversikan kedalam tabel kurva normal dari tabel 0-Z, maka diperoleh luas daerah sebesar 0,2549. Hal ini menunjukan perlakuan model pembelajaran Student Team Achivement Divison berbantuan buku saku memberikan konstribusi sebesar 25,49\% dalam mempengaruhi hasil belajar siswa materi keanekaragaman hayati MAN 1 Pontianak.

\section{Simpulan}

Berdasarkan hasil penelitian yang dilakukan bahwa perlakuan dengan menggunakan model pembelajaran kooperatif tipe STAD berbantuan buku saku dapat meningkatkan hasil belajar siswa. Hasil penelitian menunjukan skor rata-rata hasil belajar kelas eksperimen sebanyak 17,57 sedangkan pada kelas kontrol 16,29. Berdasarkan analisis data dengan menggunakan uji $U$ Mann-Whitney $\mathrm{Z}_{\text {hitung }}<\mathrm{Z}_{\text {tabel }}$ menunjukkan terdapat perbedaan hasil belajar siswa yang diajar dengan menggunakan model kooperatif Student Team Achivement Division dengan model konvensional. Nilai Effect size diperoleh sebesar 0,69 dengan kategori sedang, memberikan pengaruh sebesar $25,49 \%$.

\section{Daftar Rujukan}

Andari, T. (2015). Perbandingan Metode Eksplinsit Instuction dan Student Team Achievement Division Terhadap Prestasi Belajar Matematika Siswa dalam Pokok Bahasan Lingkaran Ditinjau dari Motivasi Belajar Siswa Kelas VII SMPN 1 Sawahan. Jurnal Edukasi Matematika dan Sains, 3(2), 1-10.

Anjelita, Ria., Syamswisna., \& Eka, A. (2018). Pembuatan Buku Saku Sebagai Media Pembelajaran Pada Materi Jamur Kelas X. Jurnal Pendidikan dan Pembelajaran, 7(7), 1-13. 
Ami, Susantini \& Raharjo. (2012). Pengembangan Buku Saku Materi Sistem Ekskresi Manusia di SMA/MA Kelas XI. Jurnal Unesa, 1(2), 10-13.

Ardian, A. (2016). Pengembangan Media Pembelajaran Berupa Buletin dalam Bentuk Buku Saku untuk Pembelajaran IPA Terpadu. Jurnal Ilmiah Pendidikan Fisika Al-Biruni, 05(1), 113.

Departemen Pendidikan Nasional. 2003. Undang-Undang Republik Indonesia No. 20 Tahun 2003 Tentang Sistem Pendidikan Nasional. Jakarta: Depdiknas

Djamarah, S.B. \& Zain A. (2013). Strategi Belajar Mengajar. Jakarta: Rineka Cipta.

Haryani, Widodo \& Afriani. (2019). Penerapan Model Discovery Learning pada Materi Pemanasan Global untuk Meningkatkan Keterampilan Berpikir Kritis Peserta Didik. Jurnal Edukasi Matematika dan Sains. Vol 7 (2), 55-64.

Junanto, T. (2010). Pengaruh Model Pembelajaran Kooperatif Tipe STAD dan TPS terhadap Prestasi Belajar ditinjau dari Sikap Ilmiah. Jurnal Pendidikan Matematika dan IPA, 1(1), 90104.

Khairiyah, Dkk. (2011). Implementasi Lesson Study Menerapkan Model STAD untuk meningkatkan Interaksi, Eksplorasi, dan Motivasi Siswa pada Bahasa Disversi di Kelas XII IPA SMA Negri 1 Pontianak. Jurnal Pendidikan Matematika dan IPA, 2(2), 28-37.

Khan, G, N. (2011). Effect of Student's Team Achivement Division STAD of Achademic Achievement of Student. Journal Asian Social Science, 4(12), 211-215.

Laksita, Suparwoko \& Sri.(2013). Pengembangan Media Pembelajaran Fisika dalam Bentuk Pocket Book pada Materi Alat Optik serta Suhu dan Kalor untuk Kelas X SMA. Jurnal Materi dan Pembelajaran Fisika, 3(1), 14-17.

Lamba. (2006). Pengaruh Pembelajaran Kooperatif Tipe STAD dan Gaya Kognitif Terhadap Hasil Belajar Siswa SMA. Jurnal Ilmu Pendidikan. Vol 13(2): 122-128.

Nazarudin. (2007). Manajemen Pembelajaran: Implementasi Konsep, Karakteristik, Metodelogi Pendidikan Agama Islam di Sekolah Umum. Yogyakarta:Teras.

Nurtanto, S. (2014) Analisis Bahan Ajar Fisika SMA Kelas XI Kecamatan Indralaya Utara Berdasarkan Kategori Literasi Sains. Jurnal Inovasi Pembelajaran Fisika, 1(1), 1-13.

Rahmawati, D. (2015) Pengaruh Pembelajaran Kooperatif STAD Berbantuan Flipbook Terhadap Hasil Belajar Sisw SMP. Jurnal Pendidikan Matematika dan IPA, 5(3), 1-12

Rusman. (2016). Model-model Pembelajaran. Jakarta: PT Raja Grafindo Persada. 
Sartika, M. (2012). Pengembangan Buku Saku Materi Sistem Ekskresi Manusia di SMA. MA Kelas XI. Jurnal Bioedu, 5(4), 1-14.

Sugiyono. (2013). Metode Penelitian Kuantitatif, Kualitatif dan R\&D. Bandung: Alfabeta

Sulistyani, D.H.N., Jamzuri, \& Raharjo, T.D (2013). Perbedaan Hasil Belajar Siswa Antara Menggunakan Media Pocket Book dan Tanpa Media Pocket Book pada Materi Kinimatika Gerak Melingkar Kelas X. Jurnal Materi dan Pembelajaran Fisika, 1(1), 164-171.

Suyono, E. (2016) Peningkatan Aktivitas dan Prestasi Belajar Kimia Melalui Pembelajaran Kooperatif STAD pada Kompetensi Laju Reaksi Kelas XI IPA3 Semester 1 SMAN 1 Polokerto Tahun Ajaran 2014/2015. Jurnal Edukasi Matematika dan Sains, 4(1), 49-60.

Sutrisno, L. (2010). Pengambilan Sampel. (Online). (http://www.Scribd.comdo c/-13190444/ meta-analisis-effect -size\#scribd.

Tiantong, L \& Teemuangsai, S. (2013). Student Team Achievement Divisions (STAD) Technique through the Moodle to Enhance Learning Achievement. Journal International Education Studies, 6 (4), 85-92.

Tran, V.D. (2013). Effects of Student Teams Achievement Division (STAD) on Academic Achievement, and Attitudes of Grade 9th Secondary School Students towards Mathematics. Internasional Journal of sciencies. 2 (1), 1-15.

Yani, A \& Ningsih, K. (2018). Implementasi Model Pembelajaran Kooperatif Tipe STAD dalam Mata Kuliah Statistik Dasar pada Program Studi Pendidikan Biologi. Jurnal Matematika dan IPA, 9(1), 31-39.

Zulhartati. (2011). Pembelajaran Kooperatif Model STAD pada Pembelajaran IPS. Jurnal Guru Membangun, 26(2), 1-8. 